\title{
Walking through volcanic mud: the 2,100-year-old Acahualinca footprints (Nicaragua)
}

\author{
I: Stratigraphy, lithology, volcanology and age of the Acahualinca section
}

\author{
Hans-Ulrich Schmincke • Steffen Kutterolf • \\ Wendy Perez • Juanita Rausch • Armin Freundt • \\ Wilfried Strauch
}

Received: 25 September 2007 / Accepted: 14 July 2008

(C) Springer-Verlag 2008

\begin{abstract}
We present the stratigraphy, lithology, volcanology, and age of the Acahualinca section in Managua, including a famous footprint layer exposed in two museum pits. The ca. 4-m-high walls of the main northern pit (Pit I) expose excellent cross sections of Late Holocene volcaniclastic deposits in northern Managua. We have subdivided the section into six lithostratigraphic units, some of which we correlate to Late Holocene eruptions. Unit I $(1.2 \mathrm{~m}$ thick), chiefly of hydroclastic origin, begins with the footprint layer. The bulk is dominated by mostly massive basaltic-andesitic tephra layers, interpreted to represent separate pulses of a basically phreatomagmatic eruptive episode. We correlate these deposits based on compositional and stratigraphic evidence to the Masaya Triple Layer erupted at Masaya volcano ca. $2,120 \pm 120$ a B.P.. The eruption occurred during the dry season. A major erosional channel unconformity up to $1 \mathrm{~m}$ deep in the western half of Pit I separates Units II and I. Unit II begins with basal dacitic pumice lapilli up to $10 \mathrm{~cm}$ thick overlain by a massive to bedded fine-grained dacitic tuff including a layer of accretionary lapilli and pockets of well-rounded pumice lapilli. Angular nonvesicular glass shards are interpreted to
\end{abstract}

Editorial responsibility: J. McPhie

H.-U. Schmincke $(\triangle) \cdot$ S. Kutterolf • W. Perez $\cdot$ J. Rausch •

A. Freundt

IFM-GEOMAR, Leibniz Institute of Marine Sciences,

Wischhofstr. 1-3,

24148 Kiel, Germany

e-mail: h-u.schmincke@t-online.de

W. Strauch

INETER, Instituto Nicaraguense de Estudios Territoriales,

Managua, Nicaragua represent hydroclastic fragmentation. The dacitic tephra is correlated unequivocally with the ca. 1.9-ka-Plinian dacitic Chiltepe eruption. Unit III, a lithified basaltic-andesitic deposit up to $50 \mathrm{~cm}$ thick and extremely rich in branch molds and excellent leaf impressions, is correlated with the Masaya Tuff erupted ca. $1.8 \mathrm{ka}$ ago. Unit IV, a reworked massive basaltic-andesitic deposit, rich in brown tuff clasts and well bedded and cross bedded in the northwestern corner of Pit I, cuts erosionally down as far as Unit I. A poorly defined, pale brown mass flow deposit up to $1 \mathrm{~m}$ thick (Unit V) is overlain by $1-1.5 \mathrm{~m}$ of dominantly reworked, chiefly basaltic tephra topped by soil (Unit VI). A major erosional channel carved chiefly between deposition of Units II and I may have existed as a shallow drainage channel even prior to deposition of the footprint layer. The swath of the footprints is oriented NNW, roughly parallel to, and just east of, the axis of the channel. The interpretation of the footprint layer as the initial product of a powerful eruption at Masaya volcano followed without erosional breaks by additional layers of the same eruptive phase is strong evidence that the group of 15 or 16 people tried to escape from an eruption.

Keywords Acahualinca footprints · Lake Managua . Erosional channeling $\cdot$ Nicaragua $\cdot$ Volcanic hazards

\section{Introduction}

Most ancient human footprints are preserved in tephra deposits (Hay 1978; Mastrolorenzo et al. 2006). The reasons for the good preservation are the fine-grained nature of ash, rapid lithification, and the likelihood of fast burial by additional tephra layers. In the case of the 3.6-Ma- 
Fig. 1 Map of western Central America and adjacent Pacific Ocean, showing Managua city, Masaya Caldera, and Lakes Nicaragua and Managua

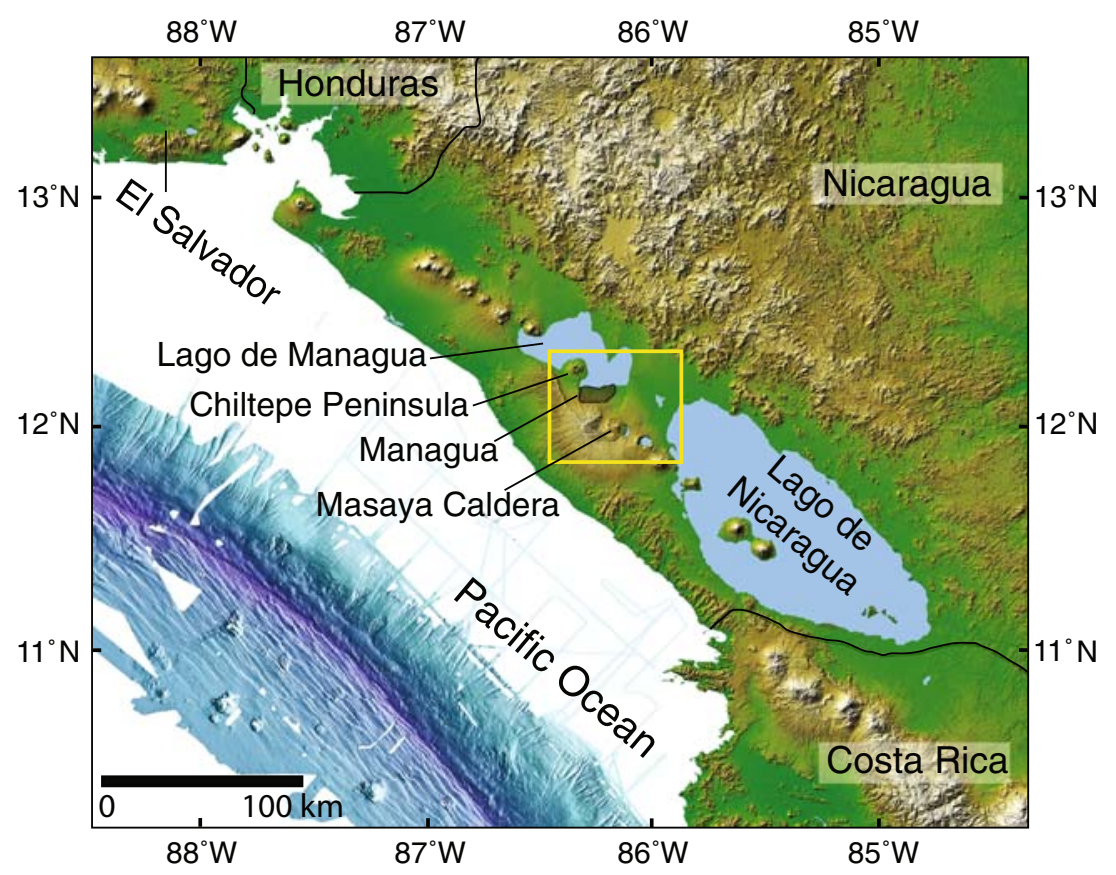

Previous work

old Laetoli footprints in eastern Africa, the plasticity of the ash and the condition of the molds are believed to be due to rainfall following an eruption and subsequent burial by more fall units (Hay 1978). In particular, phreatomagmatic tephra is the ideal substratum for preservation of tracks. Phreatomagmatic eruptions typically consist of many eruptive pulses due to the repetitive encounter of magma and water. Tephra deposited from such eruptions is moist to wet, with much fine ash adhering to larger particles, ideal conditions for imprints to be made. Such eruptive pulses may be separated by lulls lasting up to several hours or even days (e.g., Ukinrek, Self et al. 1980). Footprints are likely to have been made during the initial or at least early stages of a larger eruption, because surviving people will naturally try to escape from the site of a disaster. Fast lithification is due to the warm and moist ash, its poorly sorted, low permeability nature and the abundance of finegrained glassy particles.

Footprints made by a group of 15 or 16 people, totaling several hundred individual tracks, are exposed in two pits accessible to the public in a museum at Acahualinca, a barrio of Managua (Nicaragua) (Schmincke et al. in revision) (Figs. 1 and 2). Here, we present the general stratigraphic framework, lithology and volcanological interpretation of the entire section exposed in the pits. Based on macroscopic and microscopic analysis and chemical and mineralogical composition of the volcanic deposits, we reconstruct the nature of the volcanic eruptions and the mode of transport of the volcanic particles. We present evidence for correlations with dated tephra deposits in central Nicaragua and thereby reinterpret the age of the Acahualinca footprint layer.
In 1874, workers quarrying for building materials just south of Lake Managua came across human footprints in tuffs. The footprints were first reported by the American doctor and archaeological collector Earl Flint (1884). Scientists from the Carnegie Institute (Washington, DC, USA) carried out the first scientific analysis and excavations in 1941/42. Subsequently, a museum and a building were constructed to

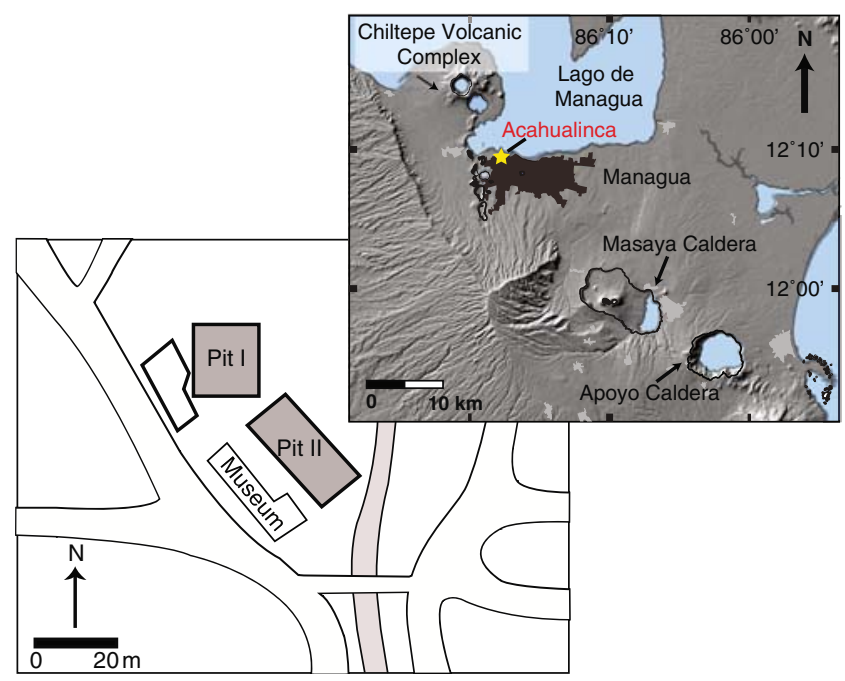

Fig. 2 Location of the Acahualinca footprint site in the Acahualinca barrio, northern Managua city, close to Lago de Managua. Gray band just east of the museum shows the main present-day drainage channel moved in 1940 to the east. Inset map: General Managua area in west central Nicaragua and major near-by volcanic centers 
protect the footprints. In the only detailed volcanological study to date, Williams (1952) argued that the footprints were made in a volcanic mudflow (as most workers have assumed since) and that the people were heading toward Lago de Managua trying to escape from a volcanic eruption. The latter interpretation has not been generally accepted. Williams (1952) also published a stratigraphic section (see below).

The age of the Acahualinca footprints has traditionally been of major interest to the people of Nicaragua and to archeologists because of its implications for the earlier population of the Central American territories and the evolution of Mesoamerican settlement and culture in general. Flint (1884) postulated an age of at least $50 \mathrm{ka}$ to as much as 200 ka. Williams (1952), who had studied the deposits in 1941, gave a qualitative age estimate of between 2 and $5 \mathrm{ka}$. This estimate was corroborated by Bryan (1973), who determined a $14 \mathrm{C}$ age of $5,945 \pm 145 \mathrm{ka}$ on silty sand "soil" below the footprint layer. Bryan (1973) estimated the time for the formation of the soil to have lasted approximately 1,000 a and concluded "the footprint layer should date around 3,000 B.C." Since then, an age of the footprints of around 6,000 B.P. is presented most often in reports and literature (e.g., Bice 1985).

\section{The sites}

The public museum "Huellas de Acahualinca" is located on the northern outskirts of Managua, about $500 \mathrm{~m}$ south of the shore of Lake Managua (Lago Xolotlán) and $0.8 \mathrm{~km}$ due east of Laguna de Acahualinca (Figs. 1 and 2). The sites are protected by a roofed building and by sidewalls (the actual museum). The footprint layer (FL) is exposed in a main, $14.3 \times 14.5 \mathrm{~m}$ pit (Pit I) (Fig. 3) with up to 4-m-high walls, oriented $\mathrm{N} 20^{\circ} \mathrm{E}$ and separated by $6.6 \mathrm{~m}$ from a

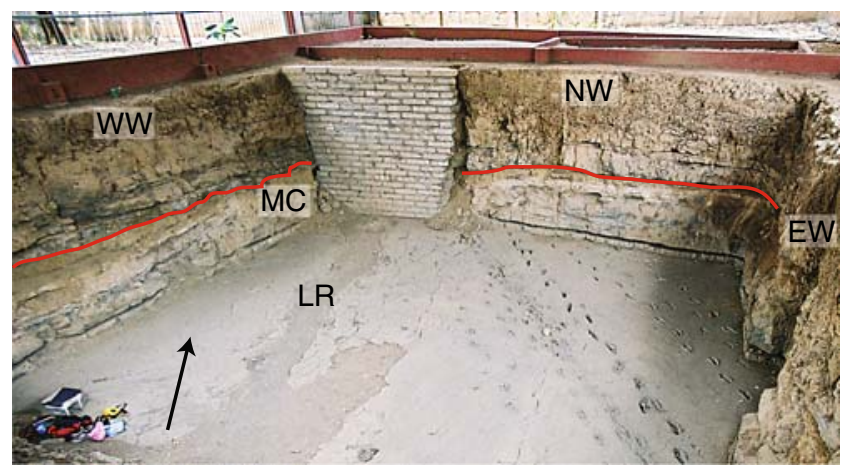

Fig. 3 Pit I showing northern (NW) and parts of eastern (EW) and western (WW) walls, footprint swath on the right and major structural elements and directions. Eastern edge of northwest directed channel (arrow and red line) (MC) on the left. Low ridge (LR) just west of the footprint swath oriented nearly north-south

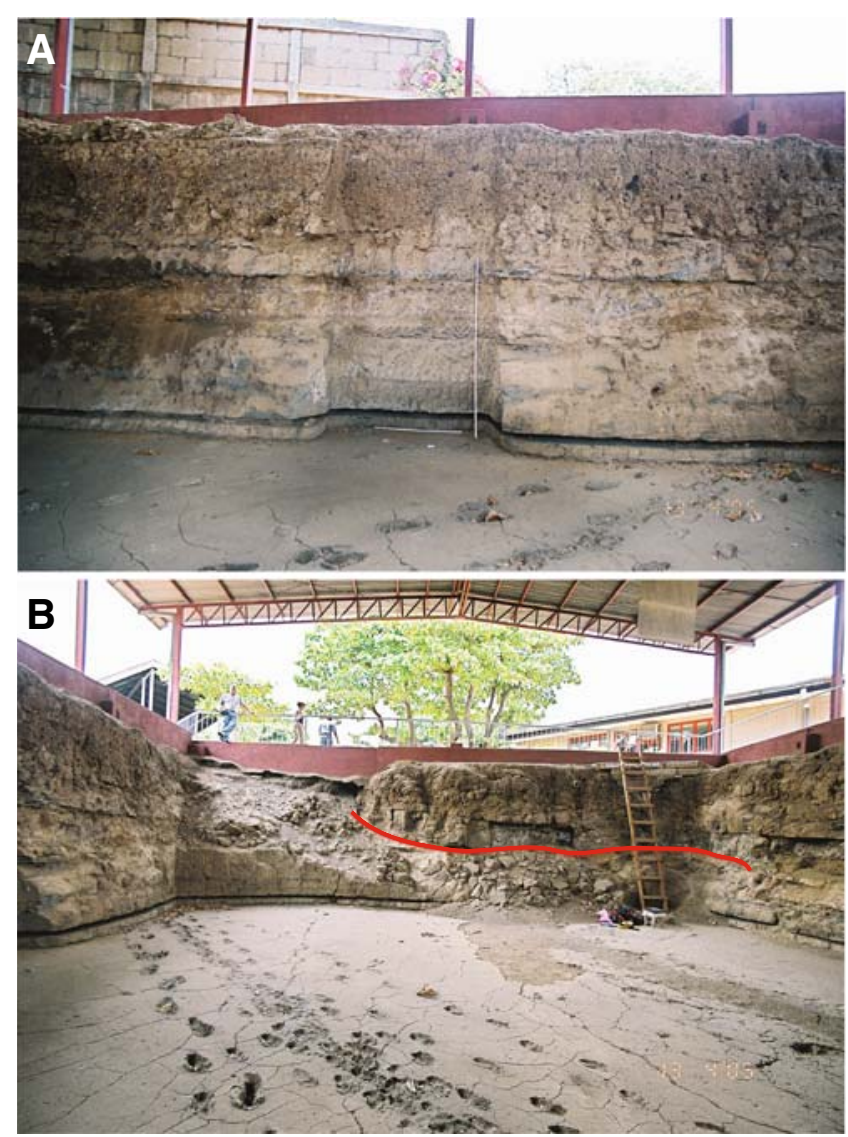

Fig. 4 Pit I: a Eastern wall (scale $2 \mathrm{~m}$ ); b Southern wall. Note cross section of NW-SE oriented channel (red line)

southern $19 \times 4 \mathrm{~m}$ pit (Pit II) oriented $\mathrm{N} 30^{\circ} \mathrm{E}$. The walls of Pit I are west wall (WW), $9.3 \mathrm{~m}$ long; north wall (NW), $11.5 \mathrm{~m}$ long; east wall (EW), $9.3 \mathrm{~m}$ long; and south wall (SW), $11.5 \mathrm{~m}$ long. A brick wall covered the western part of the north wall until 2006 (Fig. 4). As of 2006, the brick walls had collapsed and steps have been built in the eastern edge of the southern wall. The southern side is the most poorly exposed.

The deposits in the unstable sections, especially the southern side, were largely covered by spray cement in 2006. Fortunately, much of our work on the stratigraphy and lithology was carried out in 2004 and 2005. The walls at Pit II are covered almost entirely by concrete, preventing documentation of the deposits laid down on top of the footprint surface. We carried out an excavation at the southern wall of Pit II for $1 \mathrm{~m}$ to document the stratigraphy of the deposits below the footprint surface.

\section{Lithostratigraphy}

We subdivided the 4-m section of Pit I into six major lithostratigraphic units comprising approximately 24 separate beds or layers (Figs. 4, 5, 6, 7 and 8). Units I, II, V and VI consist of several layers or beds interpreted as deposits 
Fig. 5 Generalized stratigraphic section of the Acahualinca deposits in Pit I compared to stratigraphic section by Williams (1952) (Fig. 6). Bar scale in meters

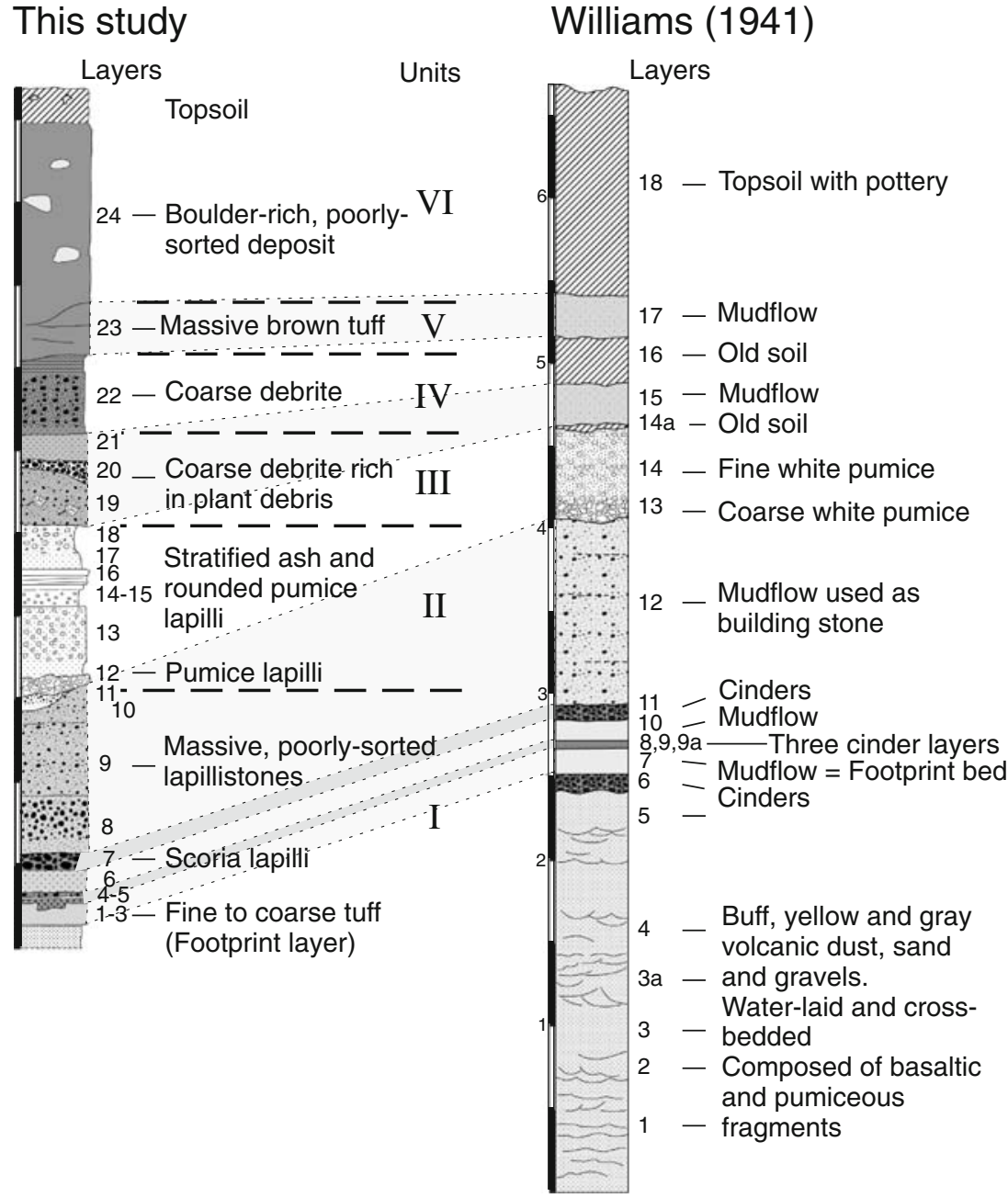

from eruptive and reworking events or pulses. There are major lateral variations in thickness and lithology of some single layers, especially in Units II-VI. One major, and several minor, unconformities make determination of original thicknesses and correlation of all layers from wall to wall difficult. A major channel filled by a distinct sedimentary facies runs through the well-exposed western and poorly exposed southern wall (Fig. 3). The overbank facies of the eastern wall and the eastern side of the northern wall contrast strongly with the channel facies as described in detail below.

\section{Unit 0 (not on the stratigraphic log Fig. 5)}

The Acahualinca FL is underlain, as shown in a temporary digging, by $10-15 \mathrm{~cm}$ of largely unconsolidated sand that represents possibly reworked tuffaceous sediment but was not studied in detail. This layer overlies at least $1 \mathrm{~m}$ of dominantly massive, unconsolidated reddish silty sand, equivalent to the tierra amarilla of previous authors (e.g., Williams 1952).

\section{Unit I (Layers 1-10) (Fig. 6a)}

Unit I, bounded by the footprint layer at its base and a pronounced erosional unconformity at its top, is subdivided into ten distinct layers or beds. It is roughly $120 \mathrm{~cm}$ thick in total along the eastern wall but thinner where strongly eroded along the western wall. Petrographically and compositionally, the layers are basaltic andesite. Phenocrysts are dominantly plagioclase with commonly less than $1 \mathrm{vol} \%$ of olivine and clinopyroxene (all components being visually estimated). There is a slight change upward to more mafic composition beginning with the fallout layer, as expressed mineralogically by a higher percentage of olivine. Sideromelane is the most common clast, some showing distinct schlieren-like layering. Most shards are angular. Tachylite makes up about 30 vol\% of the juvenile shards but increases relative to sideromelane upward in Unit I. The modal percentage of rock fragments also increases upward from 5 to $20 \mathrm{vol} \%$ in layers 8-10. Palagonitization is minor and mostly restricted to finegrained sideromelane shards. 

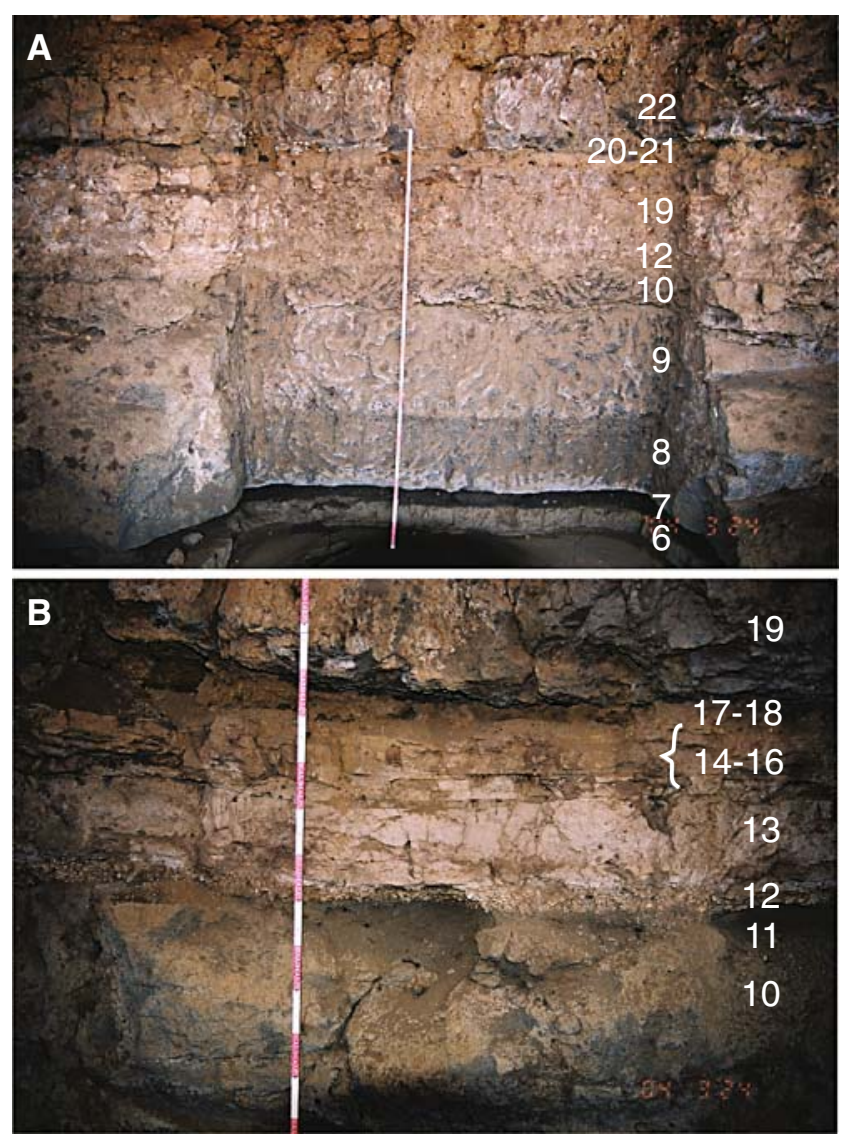

Fig. 6 Overbank facies of Units II and I along eastern and northern walls of Pit I. A Overview eastern wall; B Unit II (layers 11-18) with basal and top contacts to Units I (layer 10) and III (layer 19) (northern wall). Numbers denote layers described in the text

Layers 1-3 Layer 1 is a 3-mm-thick, fine to coarse ash, separated sharply from the assemblage of underlying sediments. Layer 2, the lower FL, making up its bulk, ranges from 3 to ca. $15 \mathrm{~cm}$ but is generally $8-12 \mathrm{~cm}$ thick.

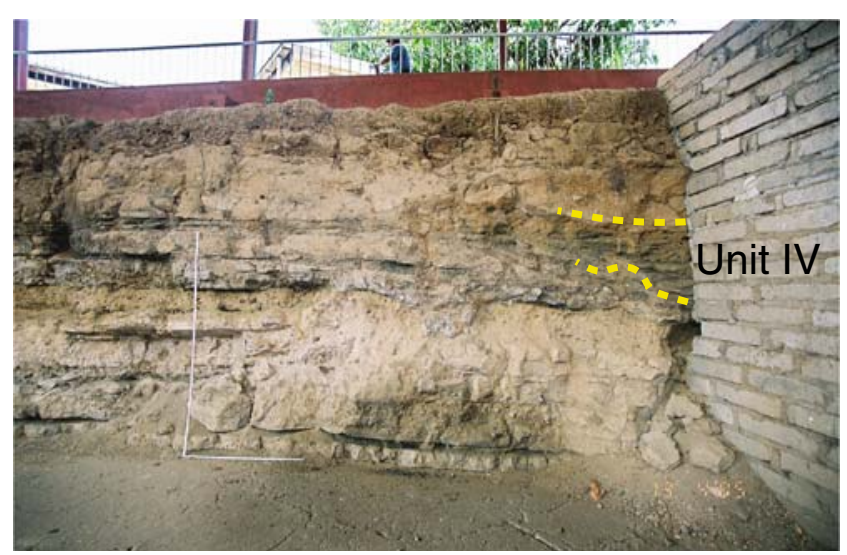

Fig. 7 Channel facies of Units II to IV along northern end of western wall. Note thick cross bedded deposits of Unit IV. Scale, marked in 10 -cm intervals, is $2 \mathrm{~m}$
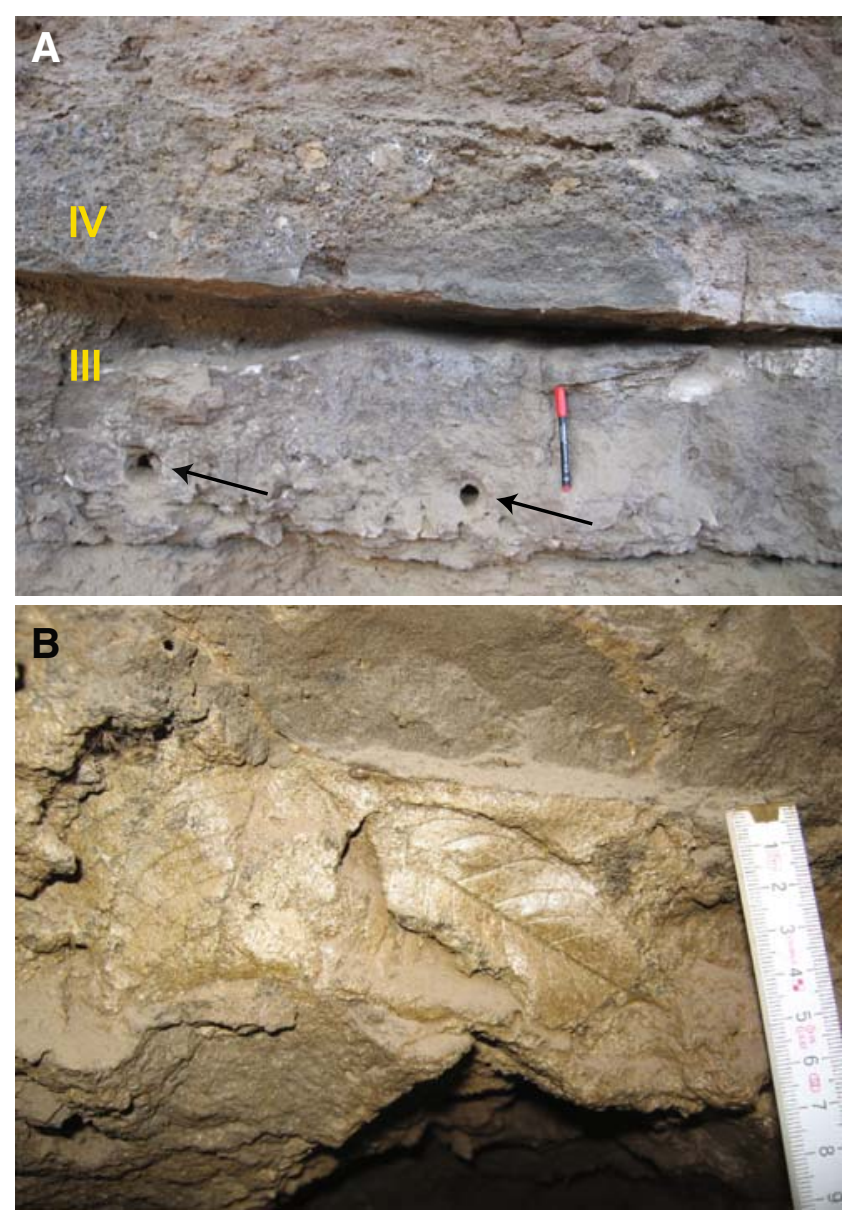

Fig. 8 (A) Units III and IV, sharply separated from each other. Note unconsolidated tephra separating the units in pocket on left and clasts of brown tuff in Unit IV. A Unit III is rich in plant debris showing two holes of twigs (arrows); B Leaf impressions of Prioria tufficola (?) in Unit III

Layer 2 is much coarser than appears at first sight and judging from the footprints. Despite the depth of some footprints, some more than $10 \mathrm{~cm}$ deep, the amount of fine ash is only moderate (ca. $20 \mathrm{vol} \%$ ), compaction being accommodated by both loss of pore space and upward displacement of wet ash from both layers 2 and 3. Most of the layer is a medium-grained poorly sorted vesicular tuff made of glassy and variably palagonitized basaltic-andesitic shards. Plagioclase phenocrysts (generally $<5$ vol \%) dominate; olivine and clinopyroxene are minor. Most sideromelane shards are angular and nonvesicular. Some Pelées tear-shaped sideromelane shards have generally $<30$ vol\% of vesicles. Small plant fragments (reed?) are common. The plant particles are rimmed by fine-grained ash. The $10-20$ vol\% vesicles in this highly vesicular lapilli tuff indicate that air or steam was captured in the ash matrix. The moderately indurated tuff has a concrete-like appearance. Layer 3 is the top of the actual FL and consists 
of fine-grained tuff up to ca. $10 \mathrm{~mm}$ thick. Abundant plant fragment molds locally embedded in the tuff resemble reeds that grows abundantly along the shores of lakes and rivers. Many plant fragments, the imprints of which also appear on the surface of layer 3, are oriented slightly north-south, subparallel to the direction of the footprint tracks, all of which are strongly aligned.

A lower bedded interval (layers 4-7) about 20-30 cm thick and an upper massive section (layers 8-10) overlie the footprint surface.

Layers 4-7 A 2-3-cm-thick distinct doublet of fine to medium-grained, loose basaltic-andesitic ash (layers 4,5) directly overlies the footprint surface but is poorly accessible. The coarser-grained lower layer contains some accretionary lapilli; the upper one is recessive. Layer 6, a 10 to $15-\mathrm{cm}$-thick, poorly sorted and well-consolidated tuff has constant thickness along all four sides of the pit. Lithologically, it resembles the FL, although it is slightly finergrained. There are slight grain-size differences in that the layer has a fine-grained mm-thick base, but on the whole it is massive. Layer 7, a dark, strongly recessive, well-sorted and unconsolidated basaltic coarse ash to lapilli layer, is up to, but generally less than, $10 \mathrm{~cm}$ thick. This layer is the most easily recognizable marker along the base of the walls of the entire pit.

Layers 8-10 A 1-m-thick group of layers consists, where least disturbed, of three relatively massive and dominantly poorly sorted and lithified basaltic-andesitic lapillistones sharply separated from each other. Layer 8 , a poorly sorted dark bed about $35 \mathrm{~cm}$ thick, is strongly inversely graded, with a finer base, a coarser top, and a sharp upper boundary. It is overlain by a similar pale gray, more massive bed (layer 9) about $45 \mathrm{~cm}$ thick. The third 10 to 20 -cm-thick massive bed (layer 10) is locally eroded.

\section{Interpretation}

Unit $I$ is interpreted to represent a distinct eruption punctuated by temporary pauses in eruptive activity. The ten layers of Unit I represent fallout and flow deposits. The eruptive and transport mechanisms and the cohesion of particles in the transporting systems varied strongly, however. In general, the massive layers were deposited wet and are dominantly phreatomagmatic in origin. The eruption of Unit I started with a dry fallout (layer 1). The FL (layers 2-3) represents a powerful eruption of coarse, steam-rich ash and lapilli (coarse mud rain) that was mobile on deposition, forming a layer varying slightly in thickness. The abundant vegetation-possibly reeds - mixed within the vesicular tuff suggests that the eruption may have started in a lake or swamp or picked up plants during eruption. The slightly uneven thickness of the fine-grained coating tuff of the FL (layer 3), ranging from 1 to more than 5 $\mathrm{cm}$ thick in the major "squeeze-ups" in tracks (Fig. 9a,b) -
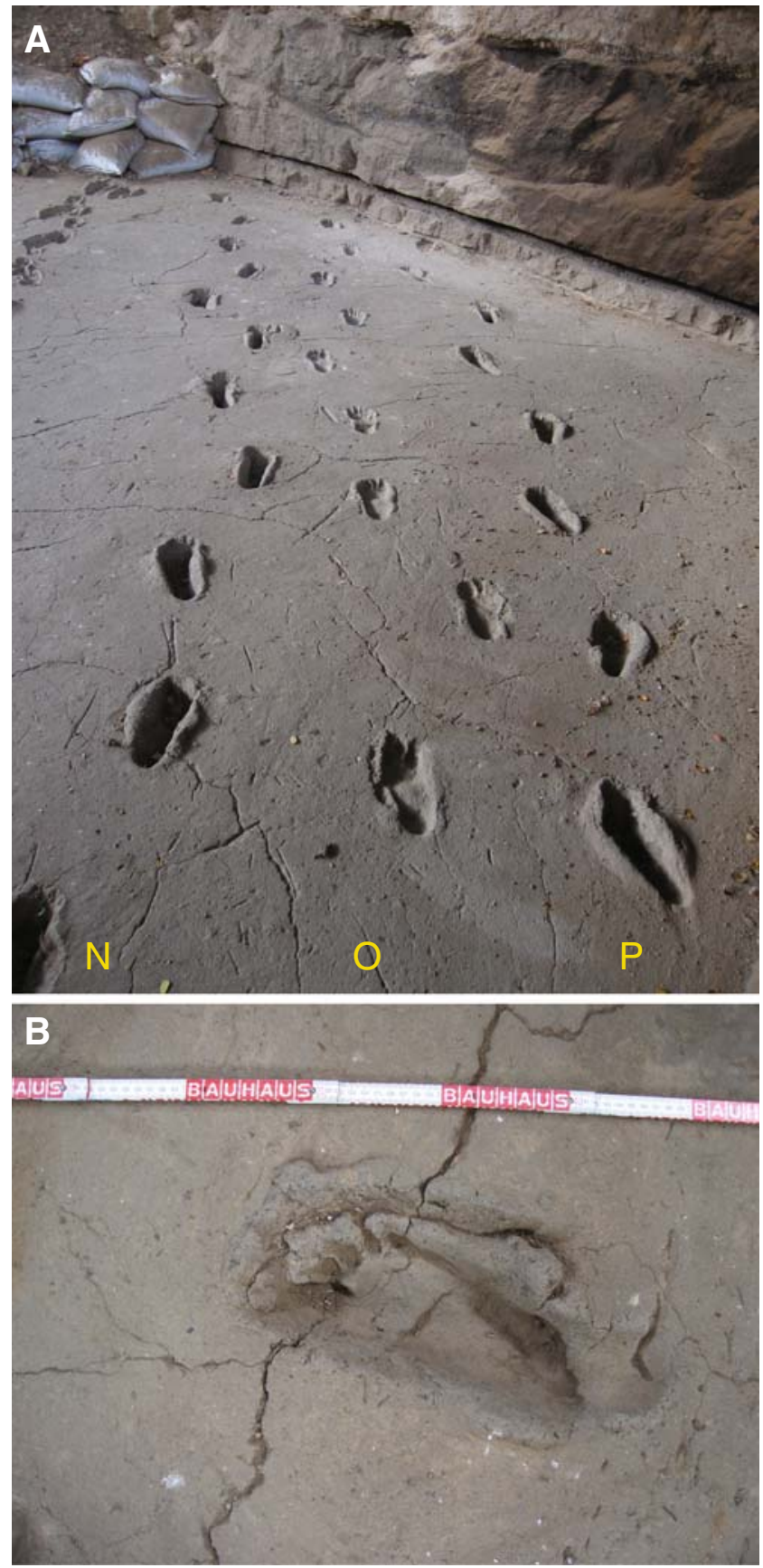

Fig. 9 A The three eastern tracks of the footprint swath in Pit I, showing footprints of two heavier (?) individuals (men?) (N, P) with deeper imprints and a central track $(\mathrm{O})$ made by a smaller individual (woman? teenager?) with clear toe imprints. Note the raised rims of squeezed up and hardened muddy tuff in the deeper footprints. For lettering of all footprint tracks (individuals) see Schmincke et al. submitted, Fig. 5. B Double track with squeezed-up rims. Note toe imprints of second person 
may reflect slight redistribution of fine-grained ash either by uneven deposition as mud rain, secondary thickening by flooding, or both. Practically all workers have previously interpreted the FL as a mudflow (lahar) following Williams (1952). Williams (1952) did not qualify his mudflow interpretation although he did imply that what we call Unit I represents an eruption. Since textural and structural criteria strongly indicate a phreatomagmatic eruption, we suggest that layers 2 and 3 represent a distal facies of wet surge deposits. Such deposits commonly show changes from proximal surge to accretionary lapilli to vesicular tuff facies with distance (e.g., Peréz and Freundt 2006). We cannot exclude the possibility that layers 2 and 3 are the distal facies of a lahar.

There is good evidence in Pit II of flooding of the footprint surface by three washouts marked by gentle sheet erosion (Schmincke et al. in revision). These washouts occurred following the passage of the people, because footprints are largely wiped-out in these 1 to 2-m-wide, broad but shallow channels. Temporary flooding is also inferred from the smooth surface of the FL, most likely caused by water advancing from nearby Lago de Managua. This inference does not contradict our conclusion that the footprints were made during the dry season (see below) because rainfall was possibly associated with the eruption. Most likely, water was rising from the lake, the FL probably being less than $1 \mathrm{~m}$ above lake level. Roughly decadal (El Nino ??) lake-level fluctuations during the past $<100$ years were up to $2 \mathrm{~m}$.

There was a clear break between the deposition of the footprint layer and the covering layers, because the upper crust of the footprint layer was brittly deformed in places by material squeezing up from below, when the people walked across the muddy surface of a coarse ash fine lapilli layer. The layer had slightly consolidated and may have dried up before the next layers were deposited.

Evidence for the origin of layers 4 and 5-partly reworked-is ambiguous, because of the present outcrop conditions.

The thin massive layer 6 probably represents wet fallout rather than a lahar because of its rather even thickness. Layer 7, the recessive dark bed, in contrast, is dry fallout, its well-sorted ash and lapilli clasts being angular, glassy, and vesicular. The massive, consolidated upper beds (layers 8-10) overlie layer 7 with a sharp planar contact and are therefore thought to be part of the same eruption. The poorly sorted deposits probably record lateral transport, possibly distal synvolcanic reworking of phreatomagmatic ash and lapilli. We show below that transport of freshly fallen tephra by lateral flow was focused in this low-lying area, consistent with the coincidence of the Acahualinca site with an ancient drainage.
Season during the eruption of Unit I tephra layers

Several lines of evidence suggest that the eruption took place during the dry season (November to May).

- The footprint surface is thoroughly mud-cracked, a dry season being in harmony with quick drying of the ash coating.

- The FL surface shows no signs of rain, such as raindrop impressions, that should have formed in the soft ash coating.

- The sharp boundaries between the different layers of Unit I imply the absence of erosion by water between the different phases of the eruption.

- The ash had relatively high viscosity, because all the sharp and well-preserved squeeze ups stayed in place and did not flow back into the footprints (Fig. 9a,b).

- The prevailing wind direction affecting the ash distribution of the initial footprint layer, in combination with the likely source area of this eruption, also suggest deposition during the dry season (wind direction to the $\mathrm{N}-\mathrm{NE}$ at 8 to $22 \mathrm{~km}$ height in the atmosphere only in the dry season; e.g., Kutterolf et al. 2007, 2008).

We therefore question the suggestion by Williams (1952) that torrential rains generated the mudflows (our Unit I), suggesting a rainy season. However, the possibility of torrential rains remains, as such rain commonly accompanies explosive volcanic eruptions.

The erosional channel

The major structural element in Pit $\mathrm{I}$ is a pronounced erosional channel with a width of at least 2-3 $\mathrm{m}$ and depth probably exceeding $1 \mathrm{~m}$ (Figs. 3, 4 and 7). Deposits of Units I and II are separated by a major channel which is discussed here because its activity began at least as early as deposition of Unit I beds. The deposition of stratigraphically higher Units (II-IV) has been influenced by this channel. The largest cross section through the channel is exposed on the southern wall, its axis running approximately parallel to a slightly elevated ridge on the floor (Figs. 3 and 4b). The steep eastern channel margin is well exposed in the middle of the northern wall, where the basal dacitic lapilli layer of Unit II is banked against a steep slope of caved-in, partly loose blocks of the massive upper lapilli tuffs of Unit I (Fig. 3). Erosional channeling has been concentrated on the western side; the eastern margin of this channel was visible east of the brick wall (collapsed in 2006) (Fig. 3). The deeper incision on the western wall resulted in a much greater lithostratigraphic complexity and deposition of additional beds not present on the slightly higher ground (overbank) represented by the eastern wall. The channel margin on the western wall (Figs. 3 and 7) 
Table 1 Whole rock analyses (XRF) of juvenile lapilli of Units I, II, and III/IV

\begin{tabular}{|c|c|c|c|c|c|c|c|c|}
\hline Acahualinca & Unit III/IV & Unit II & Unit II & Unit II & Unit II & Unit II & Unit II & Unit I \\
\hline Sample & $(2004 / 03-23-10)$ & $(617-1)$ & $(617-2)$ & $(617-3)$ & $(617-4)$ & $(2004 / 03-23-06)$ & $(2004 / 03-23-08)$ & $(2006-11-10-04)$ \\
\hline Correlation & MT & $\mathrm{CT}$ & $\mathrm{CT}$ & $\mathrm{CT}$ & $\mathrm{CT}$ & $\mathrm{CT}$ & $\mathrm{CT}$ & MTL \\
\hline $\mathrm{SiO}_{2}$ & 51.55 & 67.03 & 66.27 & 67.12 & 66.38 & 67.05 & 68.34 & 50.31 \\
\hline $\mathrm{TiO}_{2}$ & 1.11 & 0.46 & 0.47 & 0.47 & 0.48 & 0.45 & 0.43 & 1.17 \\
\hline $\mathrm{A} 12 \mathrm{O}_{3}$ & 16.55 & 15.58 & 15.90 & 15.68 & 15.61 & 15.43 & 15.30 & 16.44 \\
\hline $\mathrm{Fe}_{2} \mathrm{O}_{3}$ & 12.68 & 4.68 & 4.99 & 4.78 & 5.15 & 4.90 & 4.18 & 13.50 \\
\hline $\mathrm{MnO}$ & 0.22 & 0.14 & 0.14 & 0.14 & 0.15 & 0.14 & 0.14 & 0.26 \\
\hline $\mathrm{MgO}$ & 4.09 & 1.27 & 1.51 & 1.27 & 1.55 & 1.48 & 1.23 & 4.32 \\
\hline $\mathrm{CaO}$ & 9.10 & 4.47 & 4.53 & 4.18 & 4.43 & 4.15 & 3.74 & 9.74 \\
\hline $\mathrm{Na}_{2} \mathrm{O}$ & 2.89 & 3.99 & 3.88 & 3.95 & 3.89 & 4.07 & 4.09 & 2.58 \\
\hline $\mathrm{K}_{2} \mathrm{O}$ & 1.25 & 2.00 & 1.94 & 2.01 & 1.94 & 1.98 & 2.18 & 1.15 \\
\hline $\mathrm{P}_{2} \mathrm{O}_{5}$ & 0.30 & 0.16 & 0.15 & 0.18 & 0.21 & 0.15 & 0.14 & 0.29 \\
\hline LOI & 0.98 & 3.09 & 2.99 & 3.21 & 3.29 & 3.19 & 3.46 & 0.83 \\
\hline Sum & 100.56 & 98.87 & 99.01 & 99.17 & 99.18 & 100.78 & 99.45 & 100.50 \\
\hline $\mathrm{Co}$ & 41 & 14 & 12 & 14 & 14 & 12 & 13 & 34 \\
\hline $\mathrm{V}$ & 327 & 63 & 76 & 61 & 90 & 67 & 53 & 388 \\
\hline $\mathrm{Zn}$ & 117 & 70 & 69 & 69 & 69 & 70 & 66 & 112 \\
\hline $\mathrm{Ce}$ & 30 & 38 & 40 & 31 & 19 & 27 & 18 & 39 \\
\hline $\mathrm{Nb}$ & 7 & 6 & 7 & 6 & 4 & 4 & 3 & 2 \\
\hline $\mathrm{Ga}$ & 18 & 14 & 15 & 15 & 14 & 12 & 18 & 22 \\
\hline $\mathrm{Rb}$ & 26 & 32 & 33 & 34 & 31 & 38 & 41 & 23 \\
\hline $\mathrm{Ba}$ & 916 & 1,286 & 1,251 & 1,313 & 1,273 & 1,256 & 1,333 & 833 \\
\hline $\mathrm{Sr}$ & 447 & 309 & 329 & 322 & 322 & 318 & 309 & 430 \\
\hline $\mathrm{Y}$ & 29 & 24 & 24 & 26 & 27 & 26 & 30 & 26 \\
\hline $\mathrm{Zr}$ & 113 & 133 & 135 & 142 & 133 & 138 & 152 & 98 \\
\hline
\end{tabular}

Methods and comparative data are listed in Kutterolf et al. (2007)

may actually represent the western margin of a wider main channel because its axis points toward the west-northwest. In other words, the channel axis may have fluctuated from time to time, the main axis being oriented SE-NW. The position of this drainage channel moved little throughout deposition of all younger deposits, however, introducing many complexities to the stratigraphy in the channel area, especially along the western wall. Outcrops farther north and east excavated by Richardson and available to Williams (1952) indeed showed a channel up to $7 \mathrm{~m}$ deep and $30 \mathrm{~m}$ wide, much of the deepening having occurred after deposition of Unit I (Fig. 10).

The origin of the channel is also of interest because of the way it was covered by younger tephra. There is no gravel or other evidence of strong fluviatile erosion prior to deposition of the dacitic tephra, as also shown by Williams (1952) (his Fig. 7). Loose reworked basaltic tephra below the basal pumice lapilli layer is preserved only in local erosional pockets. The erosional channel may have started to form earlier than the presently visible main channel for several reasons. For one, the basal 10-12 cm tuff of layer 7, overlying thin layers 4-6 covering the footprint surface, thickens slightly toward the main channel axis. Secondly, the overlying, strongly recessive basal fallout layer 7 also has irregular bedding along the western wall that may indicate minor reworking. The shallow ridge in the western part of Pit I was already present during deposition of Unit I layers and may represent the eastern margin of a shallow drainage channel that later developed into a more pronounced channel. Most significantly, the thick massive units, well defined on the eastern side (layers 8-10), are more irregular and show more pronounced bedding on the western side, suggesting that some water may have been flowing in a shallow channel that caused the material to become bedded. A careful reconstruction of the morphological and drainage scenario is of interest in interpreting the position and direction of the footprint swath (Schmincke et al. in revision).

Fluvial erosion was the most likely cause of the channel. Incision of the channel by a tsunami backwash during the Chiltepe eruption of Apoyeque volcano (see below) cannot be excluded but is unlikely for several reasons. Most importantly, the massive top layers of Unit I appear to have been reasonably consolidated prior to Chiltepe pumice deposition. The presence of loose volcanic sand in small troughs in the channel underlying the basal coarse pumice is difficult to explain unless the processes for formation of the channel had already terminated. We cannot exclude the possibility, however, that the loose sand was deposited by a water wave (tsunami?) just prior to deposition of the coarse, basal, well-sorted pumice lapilli layer, which directly 
Fig. 10 a Map of footprint outcrops in the general Acahualinca area. Numbers are elevation (meters) above lake level. b Cross section of erosional channel near the present Acahualinca site. Numbers on the right side of the cross section are those of Williams (1952). Redrawn from Williams (1952, Figs. 5 and 7)

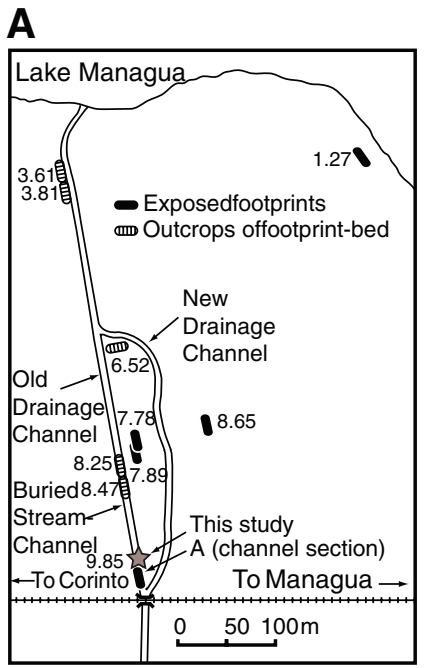

Soil layers
Cinders and thin mudflows, including footprint bed

[-- Pre-valley deposits - water - laid volcanic ejecta

D- Mudflows

White pumice layer

F: Volcanic sand \& gravel

B

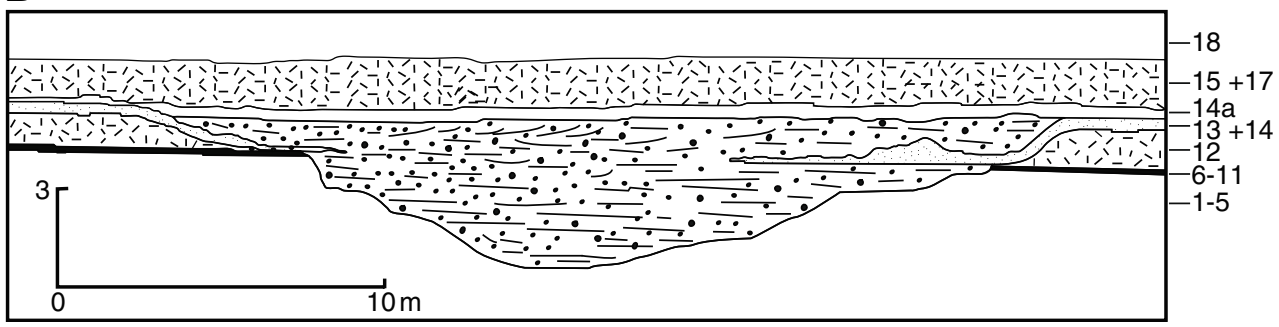

overlies the erosional channel surface. This surface is not appreciably weathered except for the local unconsolidated, reworked tuff (layer 11) (see below). Moreover, we see no signs of a back-flooding tsunami wave, which normally causes dune structures and transports a lot of loose material (wood and branches) picked up from the coastal area. In comparison, the eruption generating the Mateare Tephra, also on Chiltepe peninsula, resulted in a tsunami wave that exactly shows depositional features such as those described above within a distance comparable to that at the Acahualinca location (Freundt et al. 2006a, b, 2007).

The length of time between deposition of Units I and II is difficult to estimate. During this interval, the mafic volcaniclastics of Unit I were deeply eroded in the channel. Whether a channel existed in roughly the same position prior to the deposits of Unit I is unknown. If so, it had become completely filled by unexposed deposits below the footprint layer. While the underlying mafic tephra deposits including the footprint layer were laid down quickly (days to months - judging from the lack of erosional unconformities between individual layers), the carving of the channel could represent a longer time interval (hundreds of years) but could also have formed quickly. Freshly deposited tephra blankets are often rapidly incised following the end of an eruption, as they have destroyed the existing drainage and are easily eroded. The main direction of the band of footprints is identical to the main channel axis, suggesting that the people walked along the eastern margin of a then shallow channel. Moreover, the decreasing distance between footsteps of the Acahualinca people toward the NW suggests that they slowed down as they approached the channel (Schmincke et al. in revision). The people also used the overall regional gradient in Pit II. Here, however, three small channels where the footprints have been washed out are oriented at right angle to the tracks. A deer also walked at right angles to the main direction of the footprints. In any case, unexposed deposits below the FL had largely leveled out any initial channel.

On balance, the channel was mostly carved following deposition of Unit I but prior to deposition of the Chiltepe dacite tephra (Unit II) (i.e. between 2.1-1.9 ka), the deposition of Unit II tephra coinciding with a period of channel aggradation.

\section{Unit II (Layers 11-18) (Figs. 6 and 7)}

Unit II, basically dacitic in composition, has been subdivided into eight layers. The basal and top layers actually consist of erosional detritus not genetically part of Unit II but included for convenience. Unit II varies widely in thickness and facies, with major contrasts between an overbank facies in the east and a channel facies in the west (Figs. 6 and 7). Unit II begins $50 \mathrm{~cm}$ above the FL in the channel facies on the western wall and $1.25 \mathrm{~m}$ in the overbank area, where the pumiceous layer 12 is almost conformable on Unit I. The total thickness of Unit II is $45 \mathrm{~cm}$ on the eastern wall and northern wall and 
approximately $75 \mathrm{~cm}$ in the channel on the western wall, where it locally reaches $1 \mathrm{~m}$. The other layers of Unit II are also thicker in the channel than in the overbank facies. In the northern wall, the unit is indistinct and thicker toward the channel axis at the brick wall.

Layer $11 \mathrm{Up}$ to $10 \mathrm{~cm}$ of dark gray, unconsolidated basaltic and andesitic lapilli and ash (layer 11), possibly derived by erosion from the underlying tephra unit, fill erosional pockets in the massive underlying lapilli tuff, locally up to $20 \mathrm{~cm}$ deep. The deepest erosional channels are along the western wall.

Layer 12 Layer 12 is a well-sorted, coarse-grained dacitic pumice lapilli layer generally $<12 \mathrm{~cm}$ thick that overlies the pockets of loose detritus (layer 11) in the channel. The pumice unit, locally inversely graded, is slightly thickerbut less than $20 \mathrm{~cm}$ - in the channel on the western side than on the eastern overbank side. Large angular lapilli are $1-3 \mathrm{~cm}$ in diameter; maximum pumice size is about $10 \mathrm{~cm}$. Dense gray and banded pumice clasts amount to ca. 2 vol $\%$. The pumice lapilli contain up to about $15 \mathrm{vol} \%$ phenocrysts, mostly complex subhedral to euhedral plagioclase, up to $1 \mathrm{~cm}$ large. Large olivine crystals (up to $1 \mathrm{~cm}$ ) (the characteristic phenocryst allowing identification of the Chiltepe dacite in the field), accompanied by minor clinopyroxene, hypersthene, and minor amphibole are characteristic. Crystal clots of plagioclase with minor clinopyroxene, hypersthene, Fe/Ti-oxides and rare olivine are also common. The glassy groundmass characteristically contains feldspar microlites. Lithic clasts, ca. 20 vol\%, comprise fresh basalt and andesite with angular shape; some hydrothermally altered lithic clasts including epidotebearing clasts, and minor rhyolitic and subrounded basaltic clasts are also present.

Layer 13 A complex highly variable dacitic tephra unit overlies layer 12. A fine-grained basal tuff up to $10 \mathrm{~cm}$ thick is overlain by the central part of the unit, which is best developed on the western side but is indistinct elsewhere. In the western wall, the pumice lapilli of layer 12 are locally overlain by a pale colored, poorly to moderately sorted, dominantly massive and consolidated pumiceous tuff generally $20 \mathrm{~cm}$, but up to $40 \mathrm{~cm}$, thick. It consists largely of rounded pumice lapilli and grades into a fine-grained top that is vaguely bedded and locally cross-bedded. Local layers of well-rounded lapilli pinch out laterally. The finegrained layers in the middle of layer 13 are rich in angular glassy, partly altered shards of microlite-rich dacite and contain some $5 \mathrm{vol} \%$ of dacite and rare epidote (?)-rich hydrothermally altered (?) rock fragments.

Layers $14-16$ On the northern side, the central layer 13 is overlain by three tephra layers, up to $15 \mathrm{~cm}$ thick in total: layer $14,1 \mathrm{~cm}$ thick, thin, fine-grained; layer 15 , up to $6 \mathrm{~cm}$ thick and coarser (slightly larger pumice) with a 3 -cm-thick, indurated, fine-grained top; and consolidated layer 16, generally $5-8 \mathrm{~cm}$ thick but only locally present, finegrained tuff, well laminated on the western wall, with a massive top that stands out during weathering. The pumice lapilli in the top layers are less vesicular than at the base. At least one of the layers contains both entire and broken accretionary lapilli. In the coarser-grained part of the complex assemblage, pumice lapilli coated with schlierenlike fine ash are set in a matrix of fine glass shards.

Layers 17-18 A completely unconsolidated layer up to 35 $\mathrm{cm}$ thick overlies the dacitic tephra layers in the channel but is generally $<10 \mathrm{~cm}$ thick on the eastern side. It thickens from about $10 \mathrm{~cm}$ toward the channel and the main brick wall on the northern side to more than $15 \mathrm{~cm}$. The basal part is dark fine to coarse ash (17), whereas the main upper part contains some larger pumice lapilli (layer 18).

Interpretation and correlation

The dacitic tephra of Unit II is mineralogically, compositionally, lithologically and stratigraphically correlative with the major dacitic Chiltepe Tephra, which was produced by a large and well-dated $\left(>4 \mathrm{~km}^{3}, 2 \mathrm{ka}\right)$ Plinian eruption sourced ca. 10 $\mathrm{km}$ north of Acahualinca in Apoyeque crater (Kutterolf et al. 2007, 2008). The bulk of this eruption is represented by a widespread pumice lapilli fall fan, at least $3 \mathrm{~m}$ thick with maximum pumice clasts exceeding $15 \mathrm{~cm}$ at nearby Laguna Verde, less than $1 \mathrm{~km}$ west of Acahualinca. Williams (1952) explained the contrast in basal coarse pumice lapilli overlain by fine-grained dacitic tuffs as the result of rapid deposition of coarse pumice followed by slow fallout of fine ash. The Chiltepe eruption is now known to have been a 4-stage eruption (Kutterolf et al. 2007): major, thick Plinian fall units followed the initial sub-Plinian fallout and minor surge deposits. Subsequent unsteady eruption conditions led to stratified medial and distal fall deposits. Proximally, surge deposits are interstratified with the fall units. The transport direction of the surges was toward the southeast (Managua and Acahualinca), contrasting with the strongly westoriented fall fan.

The basal Chiltepe pumice lapilli at Acahualinca (layer 12) are poor representatives of the thick regional pumice fall blanket. Judging from the isopach map, a thickness of ca. 1-2 m would be reasonable for the Acahualinca site. We can think of several explanations - all speculative-for the greatly reduced thickness at Acahualinca.

- Removal of a significant thickness of fall pumice over a minimum area of $20 \mathrm{~m}^{2}$ (the area of the pit but 
obviously much larger). Removal must have happened during the eruption, because the overlying accretionary lapilli-bearing bed represents the waning stage of the eruption (see below). Unconsolidated pumiceous tephra can, of course, be eroded rapidly following an eruption. Nevertheless, the angularity of the pumice lapilli in layer 12 is not in harmony with them having been reworked. Likewise, the relatively even thickness across the northern and eastern walls of pit I are difficult to explain by reworking. On the other hand, layer 12 contains some angular lithic clasts, which would be consistent with a conventional fall origin.

- The pumice lapilli layer may also have been deposited from a pumice raft resembling that of the Laacher See pumice raft deposits (Park and Schmincke, 1997) washed ashore from Lake Managua. In fact, the water level of Lake Managua at that time probably was some $3 \mathrm{~m}$ higher than today. The fact that the pumice lapilli layer 12 is significantly thicker in the channel on the western wall compared to the overbank areas suggests - but does not prove - that it might have been left by a receding water level, the water surface having possibly been covered by the pumice lapilli. The presence of finegrained reworked tephra (layers 11 and 18) in pockets just below and above the dacitic tephra sequence suggests that the area may have been inundated at the time, with some basal fall pumice and lithic clasts settling immediately while much of the later pumice lapilli floated away.

- Layer 12 pumice lapilli may reflect a rapid flooding event, such as by tsunamis.

In all of these scenarios, most of the initial ca. 1-2 (?) $\mathrm{m}$ thick pumice fall must have been removed extremely rapidly at this site while the eruption was still in progress. Alternatively, the site was inundated already when the eruption started.

The complex, fine-grained, massive to bedded, pale tephra (layers 13-17) with local lenses of rounded well-sorted pumice lapilli are not easy to explain either. The phreatomagmatic nature of this phase is suggested by the abundance of dense angular dacite clasts with abundant microlites. The epidote/clinozoisite-rich rock fragments are especially interesting, because they indicate that fragmentation had propagated deeper into a hydrothermally altered halo around the deeper conduit system. The bedded deposits (layers 13-17) probably correspond to those of the final eruption phase of Chiltepe, which are known only from proximal localities around Apoyeque crater. The presence of accretionary lapilli in layer 16 clearly indicates that the Chiltepe eruption was still in progress, albeit in a late stage. Because the dacite is compositionally rather homogeneous, erosion and reworking are thought to have occurred practically contemporaneously.
We speculate that layers 13-17 may record one or more synvolcanic tsunamis. If the elevation of the Acahualinca section was stable for the past 2,000 years, the tsunamis generated by the Chiltepe eruption must have reached at least $0.5 \mathrm{~km}$ inland.

Several layers (layers 13,15, and 16) of this interval are well lithified and contrast starkly with the overlying loose deposit (layer 14) as well as the two layers of fine-grained erosional detritus at the top and base of the unit (layer 17 and 18, respectively). The lithified state suggests that the dacite tephra was slightly warm and wet when deposited, thus favoring rapid lithification.

In summary, the area around Acahualinca was probably covered by shallow water when Apoyeque volcano erupted producing the Chiltepe tephra. A major portion of the pumice lapilli fall was removed, possibly by rafting. The Acahualinca section was deposited in shallow water, the area possibly being flooded by tsunamis during the eruption.

Two distinctive massive units overlie and contrast strongly with the dacitic tephra of Unit II. Pockets of reworked, commonly loose sediment underlie each of the units.

\section{Unit III (Layers 19-21)}

Unit III is a pale gray, dominantly massive, lithified, roughly tabular, mostly fine-to medium-grained tuff (layer 19) up to about $50 \mathrm{~cm}$ thick on the eastern wall and mostly less than $40 \mathrm{~cm}$ on the western wall. The unit is highly irregular in thickness and full of holes because it is extremely rich in plant fragments: branches, leaves and some elongate reeds (Fig. 8). Where thickest on the southern wall, it is coarse-grained in the lower $70 \mathrm{~cm}$ and topped by two distinct layers, the lower $5 \mathrm{~cm}$ unconsolidated and relatively well-sorted (layer 20) and the upper 12 $\mathrm{cm}$ (layer 21) especially fine-grained but massive tuff. The unit also thickens close to the channel on the western wall, where two local tongues intruded the loose, reworked, pumiceous material overlying Unit II. In the northwest, the unit is less than $30 \mathrm{~cm}$ thick, possibly because of erosion before or during deposition of the top of Unit IV. Toward the north, Unit III thins to a few centimeters. A similar thickening of the unit is very clear toward the north on the eastern wall, where it is approximately $45 \mathrm{~cm}$ thick but is locally deeply eroded and overlain by boulder-bearing tuff. The upper $15-\mathrm{cm}$-thick finer part is present again in the northern part of the eastern wall, and on part of the northern wall, where Unit III thickens to some $60 \mathrm{~cm}$ close to the channel. About $3 \mathrm{~m}$ east of the brick wall, the unit is irregular, indistinct, and eroded. Erosion after deposition of all the units above Unit I was concentrated in the channel.

Moderately vesicular $(<50$ vol $\%$ vesicles, rarely $>50)$ sideromelane shards make up $>80 \mathrm{vol} \%$ of the heterogeneous, dominantly poorly sorted tuff. Lenses of well-sorted 
vesicular sideromelane lapilli alternate with more massive portions, part of which resemble ash rain or incomplete accretionary lapilli. The juvenile fragments are pale gray and basaltic-andesitic in composition. Crystals, dominantly plagioclase, are less abundant than in Unit I. Microlites in the sideromelane are more abundant than in Unit I tuff, with the possible exception of the footprint layer. Tachylite lapilli ranging from angular to round and from nonvesicular to moderately vesicular are less abundant than in Unit I tuffs. Rock fragments (crystalline basalt) make up $<5$ vol\%.

Unit III, rich in leaf impressions (Fig. 8) and branch molds, was deposited not long after the Chiltepe tephra, following minor erosion of the fine-grained dacitic tuffs of Unit II. The strongly consolidated and resistant Unit IIIprobably owing to its wet deposition - protected the easily erodable Chiltepe tephra. Unit III is likely the direct result of a voluminous phreatomagmatic eruption because it is dominated by slightly vesicular sideromelane lapilli, the source possibly being Masaya Crater.

Deposition from a powerful wet surge that defoliated and uprooted bushes and caused (?) some synvolcanic reworking is likely. Alternatively, some, or indeed all, of the vegetation in the unit could be largely in situ, explaining why most of the branch holes occur in the lower part of the unit. There is a certain widespread bushy plant (Prioria copaifera) that presently grows quickly on the ground and could have grown on the Chiltepe pumice within a few years. The plant has large round leaves, which strongly resemble the leaves incorporated in the deposits. We suggest that the fossil leaves first recognized by Flint (1884) and discussed by Brown (1947) are from this layer.

\section{Unit IV (Layer 22)}

Dark gray Unit IV, variably thick from 20 to $100 \mathrm{~cm}$, is separated from Unit III by a few $\mathrm{cm}$ of relatively wellsorted ash and lapilli. The complex, brown poorly sorted and massive debrite unit, varies drastically in lithology, is coarser than Unit III, and locally has a basal fine-grained tuff. Brown tuff fragments up to several $\mathrm{cm}$ in diameter are common. The top 10-20 cm are finer grained and bedded. Toward the northwestern channel axis, the unit is overlain by bedded to cross-bedded well-sorted deposits of dense, mafic, subspherical tachylite lapilli-sized and larger clasts and is up to $1 \mathrm{~m}$ thick, cutting deeply into the underlying units (Figs. 7 and 8). Unit IV is thin and deeply eroded on the northern and eastern walls. The entirely tachylitic lapilli are almost without exception composite (Herchenberg type of Bednarz and Schmincke 1990) and contain large unbroken plagioclase, clinopyroxene and olivine, the composition being distinctly more mafic than Units I and
III. Vesicularity (irregular vesicles) ranges up to approximately 50 vol\%. Some lapilli contain minor crystalline basalt inclusions. Unit IV is probably another phreatomagmatic deposit-now reworked - but is poorly accessible along the walls of the pit. The cross-bedded deposits within the channel and the extreme lithologic variation suggest that the unit represents reworked material, possibly in the aftermath of a phreatomagmatic eruption.

\section{Unit V (Layer 23)}

Unit $\mathrm{V}$ is made of relatively homogenous, massive brown tuff units about $20 \mathrm{~cm}$ thick on the western wall but thicker on the eastern wall. Unit $\mathrm{V}$ is deeply eroded on the northern and eastern walls and is cut sharply with an erosional unconformity by the deposits of Unit VI. The lower part of the unit is locally cross-bedded. The unit has not been studied in detail, because it can only be reached by ladder. It probably represents reworked material possibly associated with an eruption.

\section{Unit VI (Layer 24)}

Unit VI is a thick, complex, poorly sorted slope deposit 1$1.5 \mathrm{~m}$ thick containing boulders up to $50 \mathrm{~cm}$ in diameter and is, on the whole, rather massive and full of modern bee holes. The base of Unit VI is strongly erosional. Its top is capped by $20 \mathrm{~cm}$ of more recent debris and soil with many fragments of tiles and other artifacts.

Unit VI deposits are entirely related to secondary mass wasting such as slope wash and debris flows, perhaps related to one or more periods of torrential rains. These deposits grade into a topsoil. Pottery sherds are common in this deposit (Williams 1952).

Correlation and age of the footprint layer and the entire Acahualinca section

Bice (1985) began to establish a stratigraphy of western central Nicaragua and, more specifically, the Managua area. This area is underlain by mafic and felsic tephra deposits from the nearby Apoyo Caldera, Masaya Caldera Complex, Chiltepe volcanic complex and the Nejapa-Miraflores alignment volcanoes. Our group has recently studied the tephra deposits in more detail (mineralogy, composition, volcanology, stratigraphy, radiometric dating) and can relate major tephra units to specific volcanic centers (Freundt et al. 2006a, b; Pérez and Freundt 2006; Freundt et al. 2007; Kutterolf et al. 2007). The basaltic-andesitic tephras from the Masaya Caldera are more difficult to correlate with each other because of their great petrographic, mineralogical and compositional similarities. In contrast, the dacitic tephra units differ strongly macroscopically, texturally and com- 


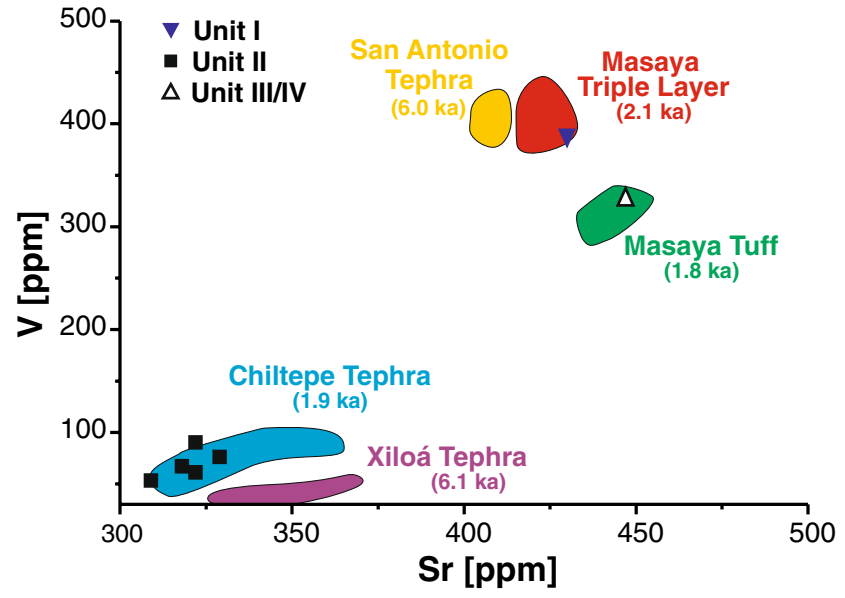

Fig. 11 Chemical composition ( $\mathrm{Sr}$ vs. V) of basaltic glass from the Acahualinca Footprint Layer (Unit I), Unit II and III/IV compared to widespread Holocene tephras in the Managua area. The Footprint Layer is correlated chemically with the MTL (Masaya Triple Layer)

positionally from the mafic tephras. Recently we identified 4 major deposits erupted from Masaya Caldera (Pérez and Freundt 2006, Pérez et al., in press): (1) the older San Antonio Tephra (SAT) ca $6 \mathrm{ka}$, (2) the 2.1 ka Masaya Triple
Layer (MTL) and (3) the youngest Masaya Tuff and (4) Ticuantepe Lapilli, both with an estimated age of $1.8 \mathrm{ka}$. Despite their overall compositional similarities, these deposits can be distinguished from each other by their internal architecture and chemical composition (Fig. 11). The SAT and the MTL are both characterized by fall as well as cross-bedded and massive phreatomagmatic tuffs. The MTL occurs in two different facies: La Concepción facies south of the caldera, and the Managua facies in the northwest (Pérez et al., in press).

We correlate Acahualinca Unit I tephra to the MTL, well dated at 2.1 ka B.P., using three lines of evidence: (1) Unit I tephra occurs in the correct stratigraphic position below the Chiltepe tephra. (2) The composition and mineralogy of basaltic lapilli from Unit I best fit the MTL composition among the Masaya tephras (Fig. 11). (3) Some Unit I layers can be well correlated to the Managua facies of the MTL as exposed in near-by outcrops (Fig. 12). For example, in two temporary excavations for drainage system in 2004 ( 1 and 4 $\mathrm{km} \mathrm{E}$ of Acahualinca), reworking was recognized in the lowermost portion of the MTL as in layer 4 discussed above. The ash of layer 1 can be correlated with $\mathrm{C} 2$, implying that the FL layer itself (layers 2-3) would be a

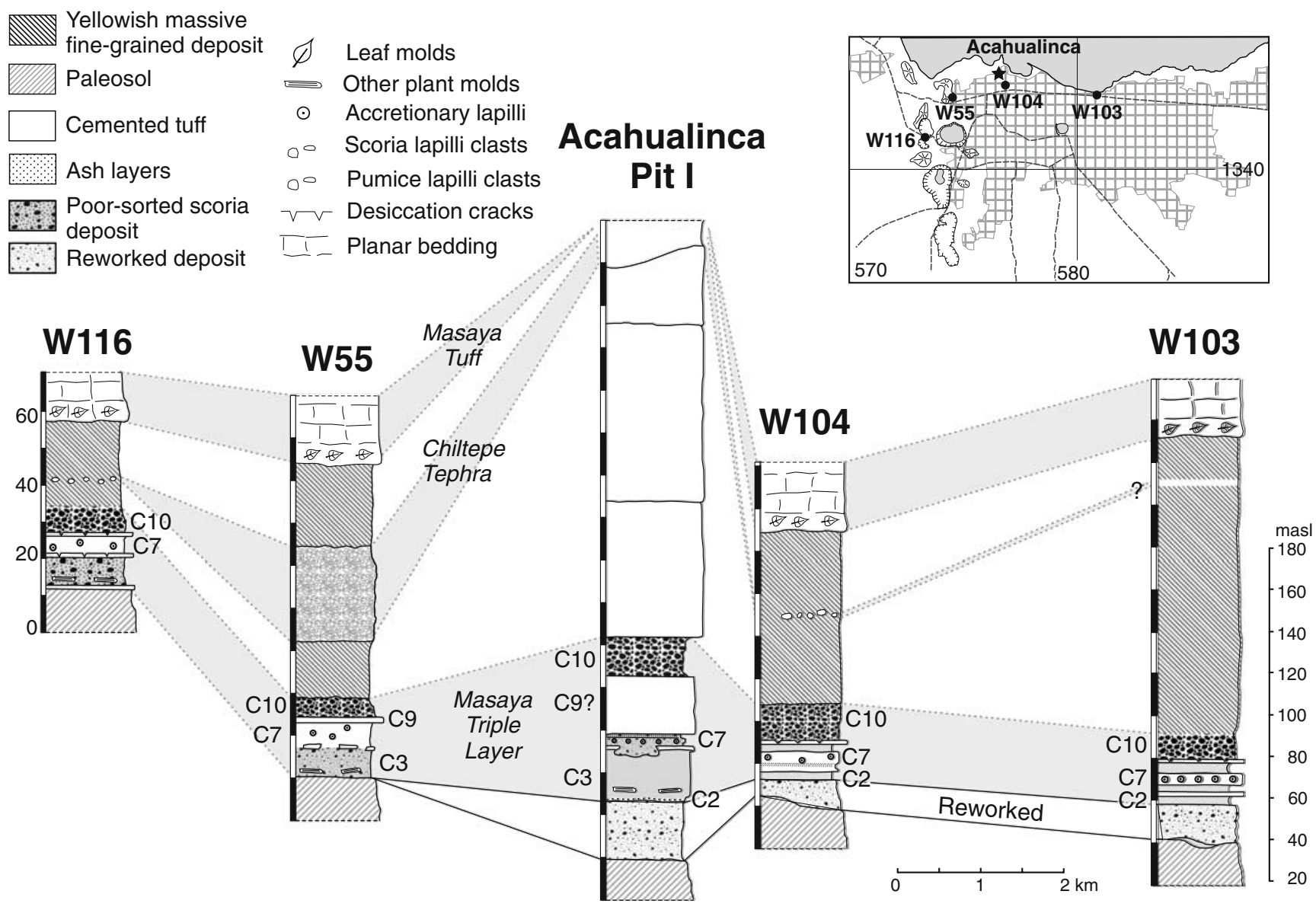

Fig. 12 Correlation of Acahualinca Unit I with nearby outcrops of Masaya Triple Layer, described in detail by Perez and Freundt 2006 
local modification of part of Unit C3, actually the MTL horizon radiocarbon dated as $2.1 \mathrm{ka}$ B.P. based on abundant plant material and molds (Pérez and Freundt 2006). The best correlation is between lapilli layer 7 at Acahualinca with subunit C10 of the MTL-Managua facies, based on thickness distribution as well as macroscopic characteristics of the particles (Fig. 12). The eruption $\mathrm{C} 10$ represents the last big event of the MTL, erupting $0.1 \mathrm{~km} 3$ of magma and forming an eruption column with a height of $24 \mathrm{~km}$ and a distribution axis toward the NW. The pronounced erosional unconformity above Unit I is not correlative to an older erosional unconformity widespread in central western Nicaragua in the area of Managua, Mateare and Masaya and dated through over- and underlying tephras to be older than $2,120 \pm 120 \mathrm{ka}$ and younger than ca. $6 \mathrm{ka}$ B.P. (Kutterolf et al. 2007). It must represent a long-lived local erosional drainage channel that was active already during deposition of Unit I beds (as shown in the western face of pit I) and continued at least until Unit IV deposition. In summary, the Acahualinca Unit I beds are most likely correlative with MTL and thus ca. 2.1 ka B.P. in age. The age of ca. 6 ka B.P. most often quoted for the FL can thus no longer be upheld.

Bice (1985) interpreted the dacitic pumice layer (our Unit II) as correlative to the Jiloá pumice dated as $6.590 \mathrm{ka}$ using charcoal from a proximal outcrop. He further interpreted the FL as a mudflow facies of the Masaya Triple Layer with a probable age of no more than $7.500 \mathrm{ka}$, concluding that the footprint layer is probably between 6,600 and 7,500 years old. While confirming Bice's age determination of the proximal Jiloa tephra, Kutterolf et al. (2007) showed that his correlation to the distal deposits in Managua was erroneous. The dacitic pumice fall (Unit II) unconformably overlying Unit I can be unambiguously correlated to the dacitic Chiltepe Tephra (CT), the largest Holocene Plinian eruption in Nicaragua. The CT contains particularly large forsteritic olivine crystals and its glass composition differs from those of the Jiloa pumice. CT dacite tephra regionally overlies the MTL. Its age is now constrained by marine pelagic sedimentation rates to be 1.9 ka (Kutterolf et al. 2007).

The leaf- and plant- rich Unit III is tentatively correlated with the compositionally similar basaltic-andesitic Masaya Tuff, the result of a huge phreatomagmatic eruption and dated as 1.8 ka B.P. (Perez and Freundt 2006; Kutterolf et al. 2007). Characteristically, the base of MT is rich in plant debris, especially leaf impressions; molds of branches and leaf impressions are also characteristic of Unit III. MT in outcrops near Acahualinca is finer-grained, however, and rich in accretionary lapilli. Local thickening and some reworking is also characteristic of several beds in Unit I, perhaps reflecting the concentration of such deposits in the central drainage area, as discussed above.

\section{Conclusions}

The famous footprint layer at Acahualinca (Managua) is interpreted to represent the initial phase of a phreatomagmatic eruption. Hence, the people who made the footprints were probably escaping from a powerful eruption. Evidence indicates that the water- or steam-rich tephra was laid down during the dry season, providing excellent conditions for the freshly made tracks to lithify quickly. Deposits of subsequent phases of the same eruption covered the hardened molds rapidly, another reason for their excellent preservation. These layers were deposited in quick succession, as evidenced by the absence of major erosional channeling or reworking.

The basal phreatomagmatic tephra (Unit I) containing the footprint layer is correlated with the basaltic-andesitic Masaya Triple Layer, erupted ca. 2,120 \pm 120 years ago from Masaya Caldera some $20 \mathrm{~km}$ farther south. A major southeast-northwest-trending erosional channel already existed during deposition of Unit I beds, although its axis then lay farther to the west. The swath of tracks of the Acahualinca people also parallels it.

The channel is overlain by a complex dacitic tephra (Unit II), up to about $50 \mathrm{~cm}$ thick in the channel, correlated unequivocally to the ca. 1.9-ka-old Plinian dacitic Chiltepe eruption based on compositional and mineralogical data. Initial Plinian fall pumice is overlain by accretionary lapillibearing hydroclastic tuffs that record one or more phreatomagmatic phases. The complex lithology and evidence for major synvolcanic erosion suggest a duration of this eruption on the order of months or years. Hydrothermally altered xenoliths in this tuff suggest a relatively deep explosion focus.

The overlying poorly sorted tuffaceous Unit III is correlated with the widespread basaltic-andesitic Masaya Tuff, dated as $1.8 \mathrm{ka}$. This deposit contains abundant branch holes and extremely well preserved leaf impressions and probably represents the deposit from which the first plant molds were described by Flint (1884), the original discoverer of the footprints in 1878 .

Acknowledgments Our work was financed by the Deutsche Forschungsgemeinschaft. This publication is contribution no. 141 of the Sonderforschungsbereich (SFB) 574 "Volatiles and Fluids in Subduction Zones" at Kiel University. We thank DA Swanson, C Principe, P Cole and J McPhie for critical comments that helped to improve the manuscript.

\section{References}

Bednarz U, Schmincke H-U (1990) Evolution of the Quaternary melilite-nephelinite Herchenberg volcano (East-Eifel). Bull Volcanol 52:426-444 
Bice DC (1985) Quaternary volcanic stratigraphy of Managua, Nicaragua; correlation and source assignment for multiple overlapping Plinian deposits. Geol Soc Am Bull 96:533-566

Brown RW (1947) Fossil plants and human footprints in Nicaragua. J Paleont 21:38-40

Bryan AL (1973) New light on ancient Nicaraguan footprints. Archaeol 26:146-147

Flint E (1884) Human footprints in Nicaragua. Am Antiquarian 6:112-114; 1885 idem 7:156-158

Freundt A, Kutterolf S, Wehrmann H, Schmincke H-U, Strauch W (2006a) Eruption of the dacite to andesite zoned Mateare Tephra, and associated tsunamis in Lake Managua, Nicaragua. J Volcanol Geotherm Res 149:103-123

Freundt A, Kutterolf S, Schmincke H-U, Hansteen TH, Wehrmann H, Pérez W, Strauch W, Navarro M (2006b) Volcanic hazards in Nicaragua: Past, present, and future. In: Rose WI, Bluth G, Carr MJ, Ewert J, Patino L, and Vallance J (eds) Volcanic hazards in Central America: Geol Soc Am Spec Pap 412:267-295, doi: 10.1130/2006.2412(08)

Freundt A, Strauch W, Kutterolf S, Schmincke H-U (2007) Volcanogenic tsunamis in lakes: examples from Nicaragua and general implications. Pure Appl Geophys 164:527-545

Hay RL (1978) Melilitite-carbonatite tuffs in the Laetoli Beds of Tanzania. Contrib Miner Petrol 67:357-367

Kutterolf S, Freundt A, Pérez W, Wehrmann H, Schmincke H-U (2007) Late Pleistocene to Holocene temporal succession and magnitudes of highly-explosive volcanic eruptions in westcentral Nicaragua. J Volcanol Geotherm Res 163:55-82, doi:10.1016/j.jvolgeores
Kutterolf S, Freundt A, Peréz W, Mörz T, Schacht U, Wehrmann H, Schmincke H-U (2008) The Pacific offshore record of Plinian arc volcanism in Central America, 1.: Along-arc correlations. Geochem Geophys Geosyst 9:Q02S01, doi:10.1029-2007GC001631

Mastrolorenzo G, Petrone P, Pappalardo L, Sheridan MF (2006) The Avellino 3780-yr-B.P. catastrophe as a worst-case scenario for a future eruption at Vesuvius. Proc Natl Acad Sci USA 103:4366-4370

Park C, Schmincke H-U (1997) Lake formation and catastrophic dam burst during the late Pleistocene Laacher See eruption (Germany). Naturwiss 84:521-525

Pérez W, Freundt A (2006) The youngest highly explosive basaltic eruptions from Masaya Caldera (Nicaragua): stratigraphy and hazard assessment. In: Rose WI, Bluth GJS, Carr MJ, Ewert J, Patino LC, Vallance JW (eds) Volcanic hazards in Central America. Geol Soc Am Spec Publ, pp 189-207

Pérez W, Freundt A, Kutterolf S, Schmincke H-U (in press) The Masaya Triple Layer: a 2,100 year old basltic multi-episodic Plinian eruption from the Masaya Caldera Complex (Nicaragua). Bull Volcanol

Schmincke H-U, Rausch J, Kutterolf S, Freundt A (in revision) Walking through volcanic mud: the 2,100 year-old Acahualinca footprints (Nicaragua) II - The Acahualinca people, environmental conditions and motivation. Quat Sci Rev

Self S, Kienle J, Huot JP (1980) Ukinrek Maars Alaska. II. Deposits and formation of the 1977 craters. J Volcanol Geotherm Res $7: 39-65$

Williams H (1952) Geologic observations on the ancient human footprints near Managua, Nicaragua. Carnegie Inst Wash Pub (Contrib Am Anth Hist 11) 596:1-32 